\title{
Physical and chemical characterisation of superficial sediment of the Ribarroja Reservoir (River Ebro, NE Spain)
}

\author{
Pilar López ${ }^{1, *}$, Josep Dolz ${ }^{2}$, Marina Arbat $^{2}$ and Joan Armengol ${ }^{1}$
}

${ }^{1}$ University of Barcelona, Fluvial Dynamics and Hydrologic Engineering (FLUMEN), Department of Ecology, College of Biology, Avda. Diagonal, 645, 08034 Barcelona, Spain.

2 Technical University of Catalonia, Fluvial Dynamics and Hydrologic Engineering (FLUMEN), Hydraulic, Maritime and Environmental Engineering Department, C/ Jordi Girona, 1-3, 08034 Barcelona, Spain.

* Corresponding author: marilopez@ub.edu

Received: 29/11/11 Accepted: 29/5/12

\begin{abstract}
Physical and chemical characterisation of superficial sediment of the Ribarroja Reservoir (River Ebro, NE Spain)

To determine the spatial heterogeneity of the physical and chemical characteristics of superficial sediments from the Ribarroja Reservoir, we have analysed particle size distribution and concentrations of major ( $\mathrm{Al}, \mathrm{Fe}, \mathrm{Si}, \mathrm{K}, \mathrm{Ca}, \mathrm{Mg}, \mathrm{Ti}, \mathrm{Mn}$ and $\mathrm{P}$ ) and minor (Mo, Nb, Zr, Y, Sr, Rb, Th, Pb, Sn, Ce, Ga, Zn, W, Cu, Co, Ni and V) elements at sixteen sites distributed along the reservoir. Globally, the sediment was quite homogeneous: the dominant grain sizes were silt and clay, and the major element composition agreed with that expected for a mixture of carbonates and weathered silicates, with moderate levels of nitrogen and phosphorus. Concentrations of minor elements did not surpass the Probable Effect Levels, although the concentrations of nickel and chromium exceeded the Threshold Effect Level. A Principal Component Analysis performed on normalised minor elements indicated that the main processes determining the variation of sediment composition were the degree of alteration/weathering of materials, and the association of some metals with organic/clay aggregates.
\end{abstract}

Key words: Superficial sediment, reservoir sediment, granulometry, Probable Effect level, Threshold Effect Level.

\section{RESUMEN}

El sedimento superficial del embalse de Ribarroja (río Ebro, NE de España): su caracterización física y química

Con el objetivo de determinar la heterogeneidad especial de las características físicas y químicas de los sedimentos superficiales del embalse de Ribarroja, se ha analizado la distribución de tamaños de las partículas y las concentraciones de los elementos mayoritarios (Al, Fe, Si, K, Ca, Mg, Ti, Mn, P) y minoritarios (Mo, $\mathrm{Nb}, \mathrm{Zr}, \mathrm{Y}, \mathrm{Sr}, \mathrm{Rb}, \mathrm{Th}, \mathrm{Pb}, \mathrm{Sn}, \mathrm{Ce}, \mathrm{Ga}, \mathrm{Zn}, \mathrm{W}$, $\mathrm{Cu}, \mathrm{Co}$, Ni y V) en dieciséis puntos distribuidos a lo largo del embalse. Globalmente, el sedimento era bastante homogéneo: el tamaño del grano estaba dominado por limo y arcilla, y los componentes de mayor tamaño se relacionan con una mezcla de carbonatos y silicatos meteorizados, con niveles moderados de nitrógeno y fósforo. Las concentraciones de los elementos minoritarios no sobrepasaron los niveles de Nivel de Toxicidad Probable, aunque el níquel y el cromo sobrepasaron el Nivel Umbral de Toxicidad. Un análisis de Componentes Principales realizado con los valores normalizados de los elementos minoritarios ha mostrado cuales son los principales procesos que determinan la variabilidad en la composición de los sedimentos, el grado de alteración/meteorización de los materiales y la asociación de algunos metales a los agregados orgánicos/arcilla.

Palabras clave: Sedimento superficial, sedimento de embalse, granulometría, Nivel de Toxicidad Probable, Nivel Umbral de Toxicidad. 


\begin{abstract}
"Represas artificiais são ecossistemas aquáticos de extrema importância estratégica, uma vez que, além da base teórica limnológica e ecológica que proporcionam, são utilizadas para diversos e variados usos que interferem com a qualidade da agua, os mecanismos de funcionamento e a sucessão das comunidades aquáticas nos rios e bacias hidrográficas."
\end{abstract}

(J. G. TUndisi \& T. MATsumura TUnDisi, 2008)

\section{INTRODUCTION}

Reservoirs play a crucial role in the transportation and sedimentation of particles along riverbeds, altering the hydrological system and retaining materials in the river. The retention of suspended material may, in some cases, reach levels higher than $95 \%$; this material may lead to negative consequences for the system, such as a decrease in hydric storage capacity and changes in the nature and amount of the sediment provided to the riverbed beyond the reservoir's dam (Loizeau et al., 1997). However, depending on the bio-geochemical characteristics of the reservoir, this accumulation of sediment may also lead to positive consequences for the utilisation of hydric resources. For example, the retention of sedimentary phosphorous in the reservoir contributes to the reduction of eutrophication in the stretch of riverbed on the other side of the dam (Armengol et al., 1986; Lopez et al., 2009).

Although the accumulated material of the sediment is composed of settled matter from the water, the physical and chemical characteristics of sediment and water column materials are different. The selection processes during transport, which are due to the selective displacement of particles according to their size and the energy required to transport them, confer a considerable spatial heterogeneity on the physical structure of the sediment. The presence of dams mainly affects the transport of particles larger than 4 microns, while the transport of clay (particles smaller than 4 microns) is relatively unaffected (Anselmetti et al., 2007). Furthermore, numerous bio-geochemical processes occur in the sediment and modify the nature and structure of the sediment material (Lopez, 2009). Greater variety and intensity of these processes lead to greater chemical heterogeneity of the sediment (Kienel \& Kumke, 2002, Kumke et al., 2005).
In many cases, contaminants and nutrients can accumulate in the sediment at higher concentrations than those observed in the water column. Due to the persistence of these materials in the sediment, monitoring their presence is an especially useful tool for evaluating the ecological quality of aquatic systems (Swartz et al., 1982). Additionally, the balance between dissolved and particulate forms of these materials depends on the physical-chemical conditions of the system, and the sediment may therefore become a source of undesirable materials for the water if the physical-chemical conditions are altered by hydrodynamic, biological or anthropogenic factors (Abrams \& Jarrell, 1995, Nurnberg, 1999). This consequence adds to the importance of the study of sediment characteristics, and knowledge of these characteristics is necessary information for the efficient management of aquatic systems.

The Ribarroja Reservoir, located on the Ebro River, receives suspended materials from three main inlets: the exits of the Mequinenza Reservoir (also on the Ebro), the Segre River, and the Matarraña River. Given that the Mequinenza dam retains over $95 \%$ of the suspended material transported by the Ebro River (Roura, 2004), the major contributors of sediment to the Ribarroja Reservoir are most likely the Reservoir itself (sediment of autochthonous origin) and the Matarraña and Segre Rivers. These different contributors could be important determinants of sediment spatial heterogeneity. The main objective of the present study is to describe the spatial variability of the physical structure and the main chemical characteristics of the superficial sediment of the Ribarroja Reservoir. The information obtained in this study will serve as a baseline for present and future evaluations of the quality of the sediment of this reservoir and will contribute to the construction of an appropriate management strategy for the system. 


\section{MATERIAL AND METHODS}

Sediment sampling was done in April 2008. Sixteen sampling points were selected (Table 1) based on the preliminary results of a precision bathymetry study of the reservoir. Given that the available results indicated the existence of a marked sediment tongue coming from the Segre River, this zone was sampled more rigorously. The positions of the sampling site were registered using GPS. Superficial sediment $(0-4 \mathrm{~cm})$ was collected using a Lenz-type dredge in a $400 \mathrm{~cm}^{2}$ area. Additionally, for seven points at which sufficiently deep sediment was extracted, the samples were subdivided in situ every $4 \mathrm{~cm}$ of depth to obtain an estimate of their vertical variability. The samples were distributed into three aliquots and kept in jars and/or PVC bags under refrigerated conditions until their analysis in the laboratory.

In the laboratory, two aliquots were allotted to a granulometric analysis, which was conducted with a Beckman-Coulter LS 230 particle analyser. One aliquot was analysed directly after dispersion with pyrophosphate and ultrasound, while the other was first treated for organic matter elimination by adding $\mathrm{H}_{2} \mathrm{O}_{2}$ before being processed in the same way as the untreated subsample. The third aliquot was dried at $70{ }^{\circ} \mathrm{C}$ until it reached a constant weight for dry weight determination. This dry material was then ground using an agate mortar until it was completely homogenised. The concentrations of carbon (C) and nitrogen $(\mathrm{N})$ in the dry material were determined using an elemental $\mathrm{CN}$ auto-analyser. For the determination of the most abundant elements, X-ray fluorescence (XRF; Panalytical, PW2400) was used after fusion at $1100^{\circ} \mathrm{C}$ with Lithium tetraborate. The concentration of trace metals was also determined using XRF after adhesion using Elvactite 2044 and posterior pressing.

\section{RESULTS AND DISCUSSION}

\section{Physical structure of the superficial sediment}

Throughout the majority of the Reservoir, the sediments are of a lime-clay texture, with a lime percentage $(4 \mu \mathrm{m}<\phi<63 \mu \mathrm{m})$ of between $56 \%$ and $74 \%$ and a clay percentage $(\phi<4 \mu \mathrm{m})$ of between $18 \%$ and $43 \%$. The G, $\mathrm{J}$ and $\mathrm{D}$ stations are exceptions, and sediments from these sites present a relatively elevated percentage of sands $(\approx 10 \%)$ along with a lower lime proportion (Fig. 1).

Regarding the texture of the sediment, it is important to note the similarity between the sediments located in the stretch next to the dam (stations $\mathrm{L}$ through $\mathrm{P}$ ) and the station located at the tail end of the reservoir (station A). At the river

Table 1. Description and location of the sampling points. Descripción y localización de los puntos de muestreo.

\begin{tabular}{|c|c|c|c|c|}
\hline Station & Description & Latitude & Longitude & depth meters \\
\hline A & Reservoir Entrance & 273791 & 4582544 & 10.9 \\
\hline B & Segre River & 274711 & 4582674 & 3.5 \\
\hline $\mathrm{C}$ & Sediment Head & 275271 & 4582104 & 8.9 \\
\hline $\mathrm{D}$ & Sediment Head & 275261 & 4582174 & 7.6 \\
\hline $\mathrm{E}$ & Sediment Head & 276881 & 4582034 & 9.7 \\
\hline $\mathrm{F}$ & Sediment Head & 276911 & 4582404 & 5.4 \\
\hline G & Sediment Head & 277571 & 4582504 & 8.2 \\
\hline $\mathrm{H}$ & Middle Stretch & 278681 & 4581554 & 12.6 \\
\hline $\mathrm{I}$ & Middle Stretch & 279181 & 4580514 & 15.3 \\
\hline $\mathbf{J}$ & Middle Stretch & 279881 & 4577634 & 17.4 \\
\hline $\mathrm{K}$ & Middle Stretch & 277311 & 4573984 & 18.2 \\
\hline $\mathrm{L}$ & Middle Stretch & 278331 & 4570244 & 21.3 \\
\hline M & Matarraña Entrance & 279351 & 4568714 & 17.5 \\
\hline $\mathrm{N}$ & Dam Stretch & 281101 & 4568614 & 24.2 \\
\hline $\mathrm{O}$ & Dam Stretch & 283211 & 4569654 & 26.3 \\
\hline $\mathrm{P}$ & Dam Stretch & 283921 & 4569894 & 26.3 \\
\hline
\end{tabular}




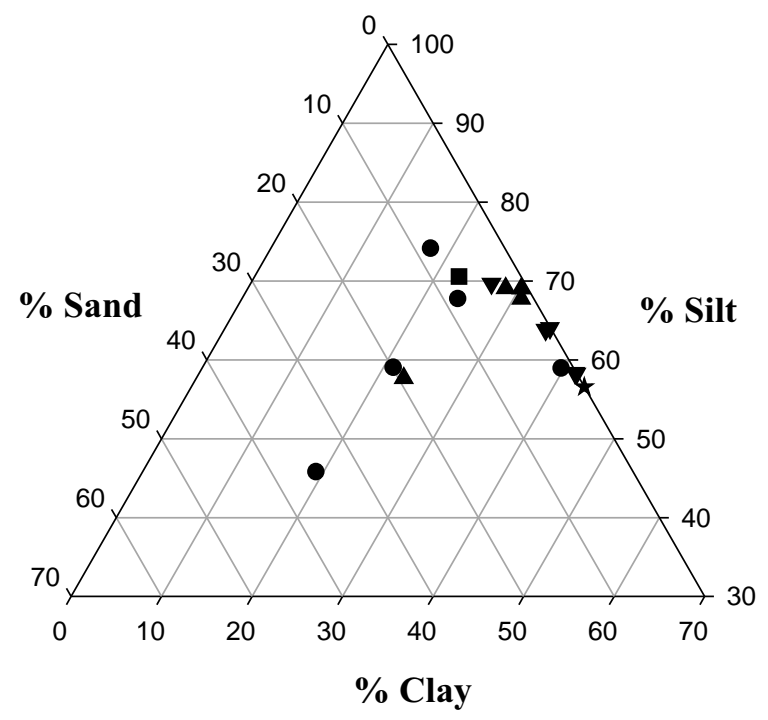

Figure 1. Shepard diagram indicating the percentage composition of clay, silt and sands in the superficial sediments of Ribarroja. The symbols indicate the different stretches. Star: station A; square: station B; circles: stations C through G; triangles: stations $\mathrm{H}$ through $\mathrm{K}$; inverted triangles: stations L through P. Diagrama de Shepard indicando la composición porcentual de arcilla, limo y arena en los sedimentos superficiales de Ribarroja. Los símbolos indican los diferentes tramos. Estrella: estación A; cuadrado: estación B; círculos: estaciones de la $C$ a la $G$; triángulos: estaciones de la $H$ a la $K$; triángulos invertidos: estaciones de la L a la P. bends (stations $\mathrm{H}$ through $\mathrm{K}$ ), the sediment shows a similar structure, but with a slightly higher percentage of lime. In the upper stretch, from the entrance of the Segre River to the beginning of the meandering zone (stations $\mathrm{C}$ through $\mathrm{K}$ ), the greatest variability in sedimentary texture is found. Some sediments in this region are of a lime-clay type (station C), while others (station $\mathrm{G})$ are of a sandy-clay type, which can be linked to the furthermost frontal zone of the sediment entrance proceeding from the Segre River.

The statistical parameters of the particle distribution observed for each sample depend on such factors as the time of transport, the type of deposition environment, and the energy of the sedimentation environment (Stevens et al., 1996, Garcia et al., 2005). The results (Table 2) show elevated values for the standard deviation of particle size (especially for stations D, G and J), evidencing a highly heterogenic sedimentary environment. In every reservoir, the distribution of particle size shows positive asymmetry, indicating that the sediment is formed by a mixture of mostly fine materials. Furthermore, in Ribarroja the asymmetry is closely related to the kurtosis, which (like the standard deviation) hints at

Table 2. Statistical parameters of the distribution of particle sizes in the superficial sediment. Parámetros estadísticos de la distribución de partículas en el sediment superficial.

\begin{tabular}{crrrr}
\hline Station & Mean micron & SD & Asymmetry & Kurtosis \\
\hline A & 7.2 & 7.5 & 2.1 & 5.8 \\
B & 20.0 & 26.9 & 2.8 & 9.4 \\
C & 9.5 & 14.5 & 4.6 & 28.1 \\
D & 46.3 & 92.1 & 3.6 & 14.0 \\
E & 22.9 & 42.1 & 4.5 & 25.3 \\
F & 23.1 & 28.0 & 2.5 & 7.3 \\
G & 106.9 & 187.9 & 2.8 & 8.9 \\
H & 13.3 & 17.9 & 3.7 & 18.5 \\
I & 11.2 & 14.1 & 3.7 & 20.4 \\
J & 43.9 & 83.0 & 3.6 & 14.7 \\
K & 10.4 & 11.5 & 3.5 & 21.0 \\
L & 8.1 & 8.5 & 2.5 & 8.9 \\
M & 7.8 & 9.1 & 2.7 & 9.7 \\
N & 9.9 & 11.3 & 3.8 & 24.4 \\
O & 15.3 & 20.3 & 3.1 & 12.1 \\
P & 7.5 & 8.5 & 2.7 & 9.1 \\
\hline
\end{tabular}


the grade of selection of the sedimented material. Station A presents the lowest asymmetry and kurtosis values of all sampling sites (Table 2), which indicates low material selection that leads to a mixture of particles not dominated by a particular fraction. On the other hand, those stations immediately posterior to the entrance of the Segre River (stations C and E) and the entrance of the Matarraña River (station $\mathrm{N}$ ) are the ones that present the highest values of these parameters, indicating that these zones have sedimentation which is highly selective for very fine materials.

The distribution of particle size in the sediment is related to the content of its organic material, as organic material can incorporate itself into microaggregates of clay and lime or even adsorb itself onto their surfaces (Zonta, et al., 1994). The comparison between the size spectrum of an untreated sediment sample and another sample from the same location in which the organic material has been eliminated provides a measurement of the particle size of the organic matter (Fig. 2). The results indicate that most of the organic matter is present in the lime fraction because when organic matter is eliminated, the percentage of lime decreases as the smaller-sized clay fraction increases (Fig. 2). This pattern appears throughout most of the reservoir, but it is especially evident in those stations situated on the final stretch (stations $\mathrm{K}$ through $\mathrm{P}$ ). In some stations located on the superior and medium stretches (D, E, G and $\mathrm{J}$ ), the decrease in the proportion of lime due to the elimination of organic material is not associated with an increase in the finer fraction but instead with an increase of the thicker fraction. Although these results must be interpreted with caution, as these stations are characterised by their elevated heterogeneity, the change observed in percentage of composition could correspond to the presence of abundant organic particles of a size similar to the lime and clay (i.e., under $63 \mu \mathrm{m}$ ) mixed with sands of inorganic nature. These results suggest the presence of an accumulation of small-sized organic matter in the higher heterogeneity sedimentary environments in the upper stretch of the reservoir.

\section{Chemical characterisation of the superficial sediment most abundant elements}

The elemental composition of the sediment of the Ribarroja Reservoir corresponds to the composition expected for a mixture of weathered silicates and carbonates. Silicon, aluminium and potassium, the main components of weathered silicates, are found in high concentrations, while the concentration of calcium, an element mainly associated with carbonates, is present in the same order as silica (Table 3). Regarding those elements associated with organic matter, the con-

Table 3. Mean concentration, standard deviation (SD) and variation coefficient (CV = Mean*100/SD) of the most abundant elements in the superficial sediment of Ribarroja. Concentración media, Desviación Estándar $(S D)$ y coeficiente de variación $(C V=$ Media*100/SD) de los elementos más abundantes en el sedimento superficial de Ribarroja.

\begin{tabular}{lcccc}
\hline & & Mean & SD & CV \\
\hline $\mathrm{TC}$ & $\%$ & 5.5 & 0.6 & 10.7 \\
$\mathrm{TN}$ & $\%$ & 0.2 & 0.1 & 22.0 \\
$\mathrm{P}$ & $\mathrm{mg} / \mathrm{g}$ & 1.2 & 0.2 & 15.6 \\
$\mathrm{Si}$ & $\mathrm{mg} / \mathrm{g}$ & 171.4 & 15.4 & 9.0 \\
$\mathrm{Ca}$ & $\mathrm{mg} / \mathrm{g}$ & 138.0 & 13.4 & 9.7 \\
$\mathrm{Al}$ & $\mathrm{mg} / \mathrm{g}$ & 69.1 & 11.8 & 17.0 \\
$\mathrm{Fe}$ & $\mathrm{mg} / \mathrm{g}$ & 32.8 & 4.7 & 14.4 \\
$\mathrm{Ti}$ & $\mathrm{mg} / \mathrm{g}$ & 3.0 & 0.3 & 11.0 \\
$\mathrm{~K}$ & $\mathrm{mg} / \mathrm{g}$ & 21.0 & 3.0 & 14.5 \\
$\mathrm{Mg}$ & $\mathrm{mg} / \mathrm{g}$ & 12.9 & 1.5 & 11.8 \\
$\mathrm{Mn}$ & $\mathrm{mg} / \mathrm{g}$ & 0.6 & 0.1 & 11.3 \\
\hline
\end{tabular}


centrations of $\mathrm{N}$ and phosphorus $(\mathrm{P})$ present values akin to those of moderately eutrophic systems (Lopez \& Morgui, 1993), with an N/P stoichiometric relationship that oscillates between 3 and 5 (expressed in atoms); this result indicates that the sediment is poor in $\mathrm{N}$ content with respect to organic matter. It is important to note that the P/Al relation in the superficial sediment presents a mean value of 16 . Because these sediments have important carbonate contents, this value suggests that phosphorous retention by the sediment is very near saturation (Jensen et al., 1992, Lopez et al., 2006).
Analyses of the subsamples taken from different depths (between 0 and $10 \mathrm{~cm}$ ) show that the superficial sediment is nearly homogeneous for the most abundant elements, with the variation coefficient being lower than $3 \%$ for all the analysed elements. With respect to the longitudinal variation observed along the reservoir, aluminium, potassium, and iron show very similar patterns of variability. These elements present uniform and elevated concentrations on the lower stretch (stations $\mathrm{K}$ through $\mathrm{P}$ ), while in the tail and at the Segre River (stations A through C), similar yet more varying concentrations are ob-
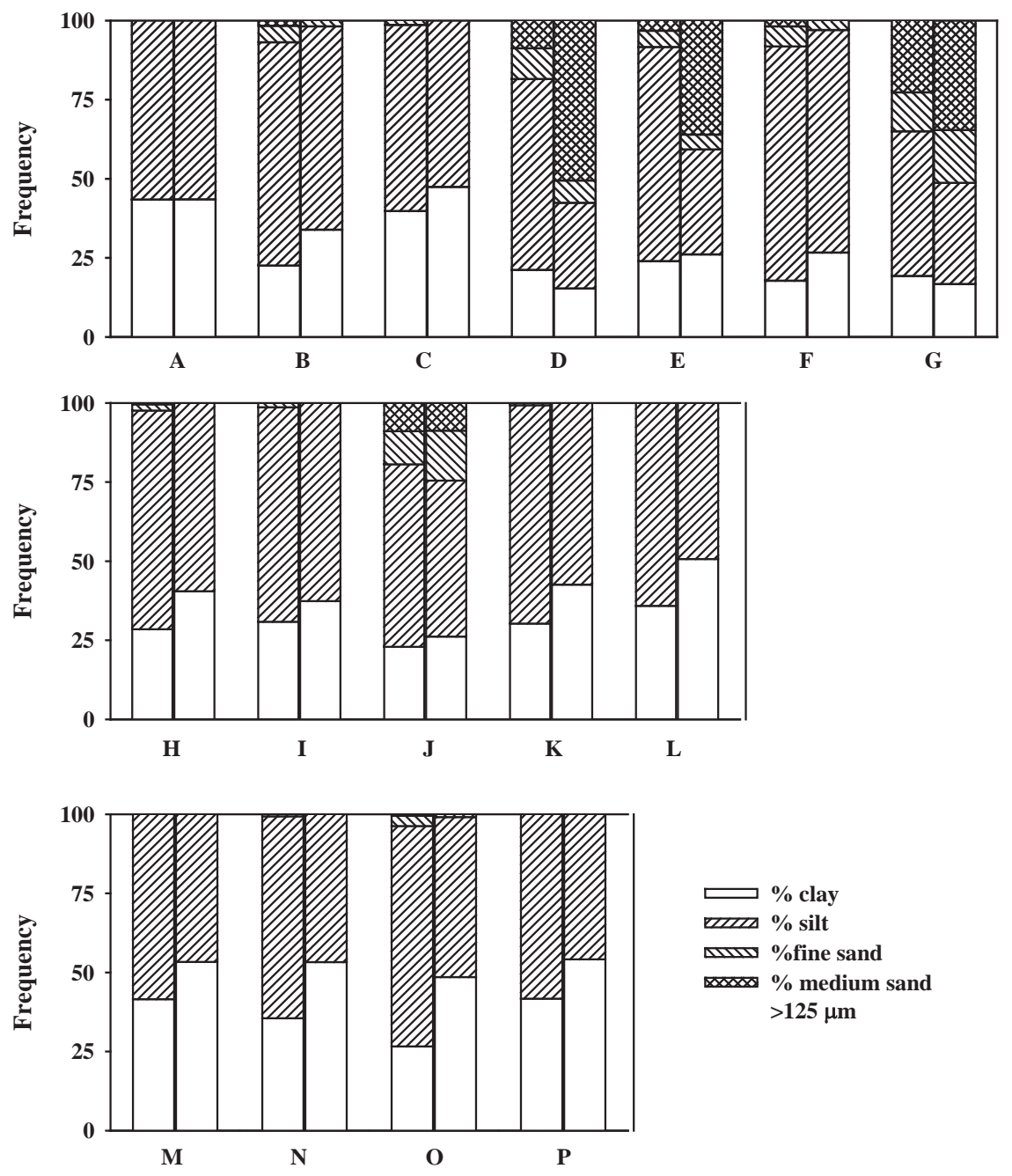

Figure 2. Percentages of clay, silt and sands in untreated replicas (left) and in replicas where the organic matter has been eliminated (right). Tanto por ciento de arcillas, limos y arenas en réplicas no tratadas (izquierda) y en réplicas en las que la materia orgánica ha sido eliminada (derecha). 
served. The intermediate stretch shows the greatest variability, along with the lowest concentrations of the reservoir (Fig. 3A). Calcium and silica follow a somewhat different variation pattern; the largest concentrations for these materials are in the zone between stations $\mathrm{D}$ and $\mathrm{K}$, with silica maximums very clear at stations $\mathrm{D}$ and $\mathrm{G}$ (Fig. 3B). $\mathrm{N}$ and $\mathrm{P}$ tend to accumulate in the lower stretch, where $\mathrm{N}$ reaches values close to $3 \mathrm{mg} \cdot \mathrm{g}^{-1}$, and $\mathrm{P}$ reaches values close to $1.5 \mathrm{mg} \cdot \mathrm{g}^{-1}$ (Fig. 3C). The pattern of $\mathrm{C}$ variability is similar to that of the concentration of $\mathrm{Ca}$, with the largest concentrations $(6.8 \%)$ being found at stations $\mathrm{F}$ and $\mathrm{G}$. This observation suggests that
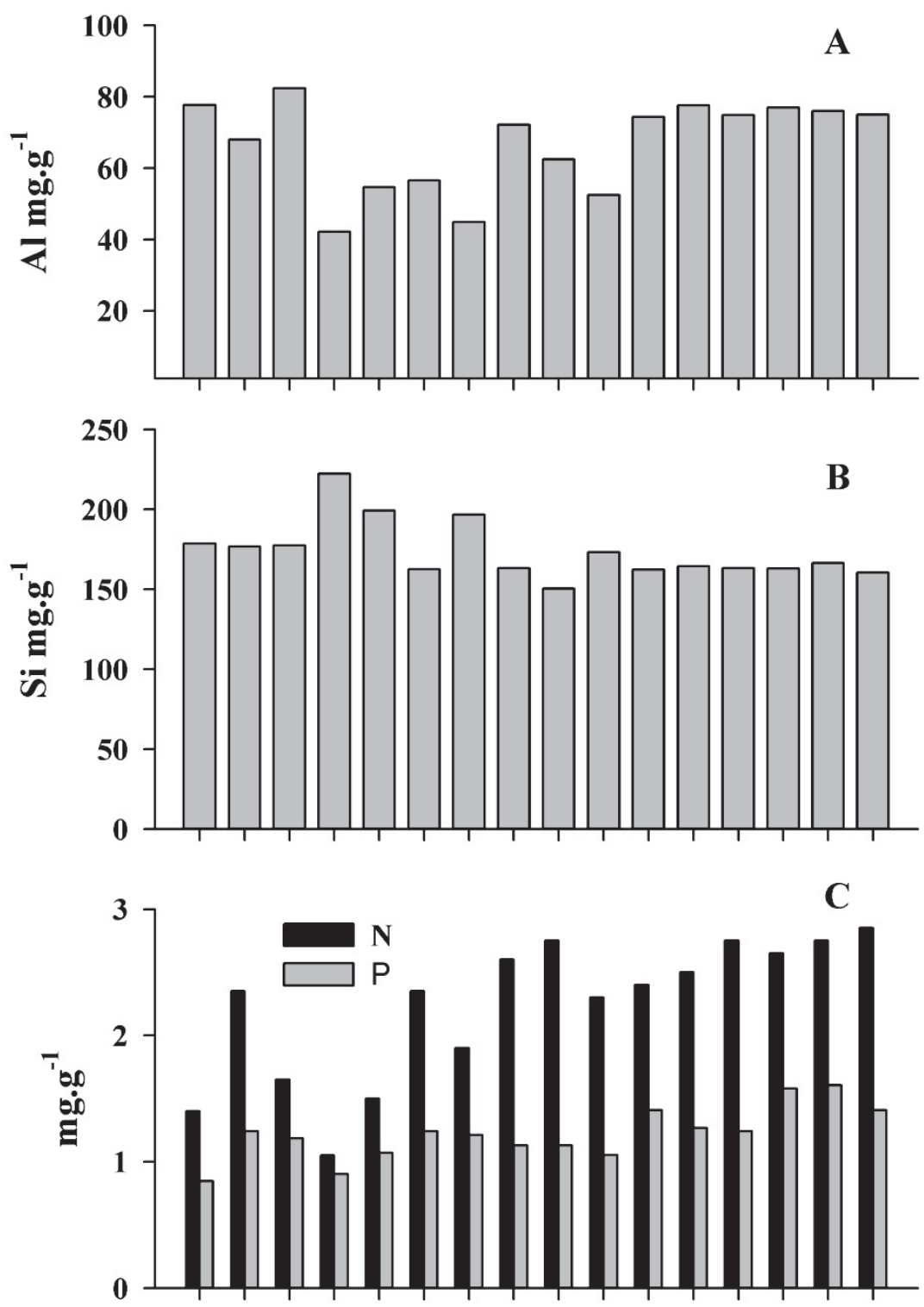

$\begin{array}{lllllllllllllllll}\text { A } & \text { B } & \text { C } & \text { D } & \text { E } & \text { F } & G & \text { H } & \text { I } & \text { J } & \text { K } & \text { L } & \text { M } & \mathbf{N} & \mathbf{O} & \mathbf{P}\end{array}$

Figure 3. Spatial variation along the reservoir of the concentrations of aluminium (A), silicon (B) and nitrogen and phosphorous (C) in the superficial sediment along the reservoir. Variación espacial a lo largo del embalse de la concentración de aluminio (A), silicio $(B)$ y nitrógeno y fósforo $(C)$ en los sedimentos superficiales. 
the variability of $\mathrm{C}$ in the sediment of Ribarroja is more closely associated with the inorganic fraction than with the organic fraction. However, the elemental coefficient between $\mathrm{C}$ and $\mathrm{Ca}$ is always greater than 1 , with the amount over 1 indicating the fraction of $\mathrm{C}$ associated with organic matter. This value is, on average, higher in the final stretch (stations $\mathrm{K}$ through $\mathrm{P}$ ), although it also presents two significant maximums at station B (Segre River on the confluence with the reservoir) and at station $\mathrm{G}$ (Fig. 4A).

The analysis of the elemental quotients provides additional information about the biogeochemical dynamics of the sediment (Lopez et
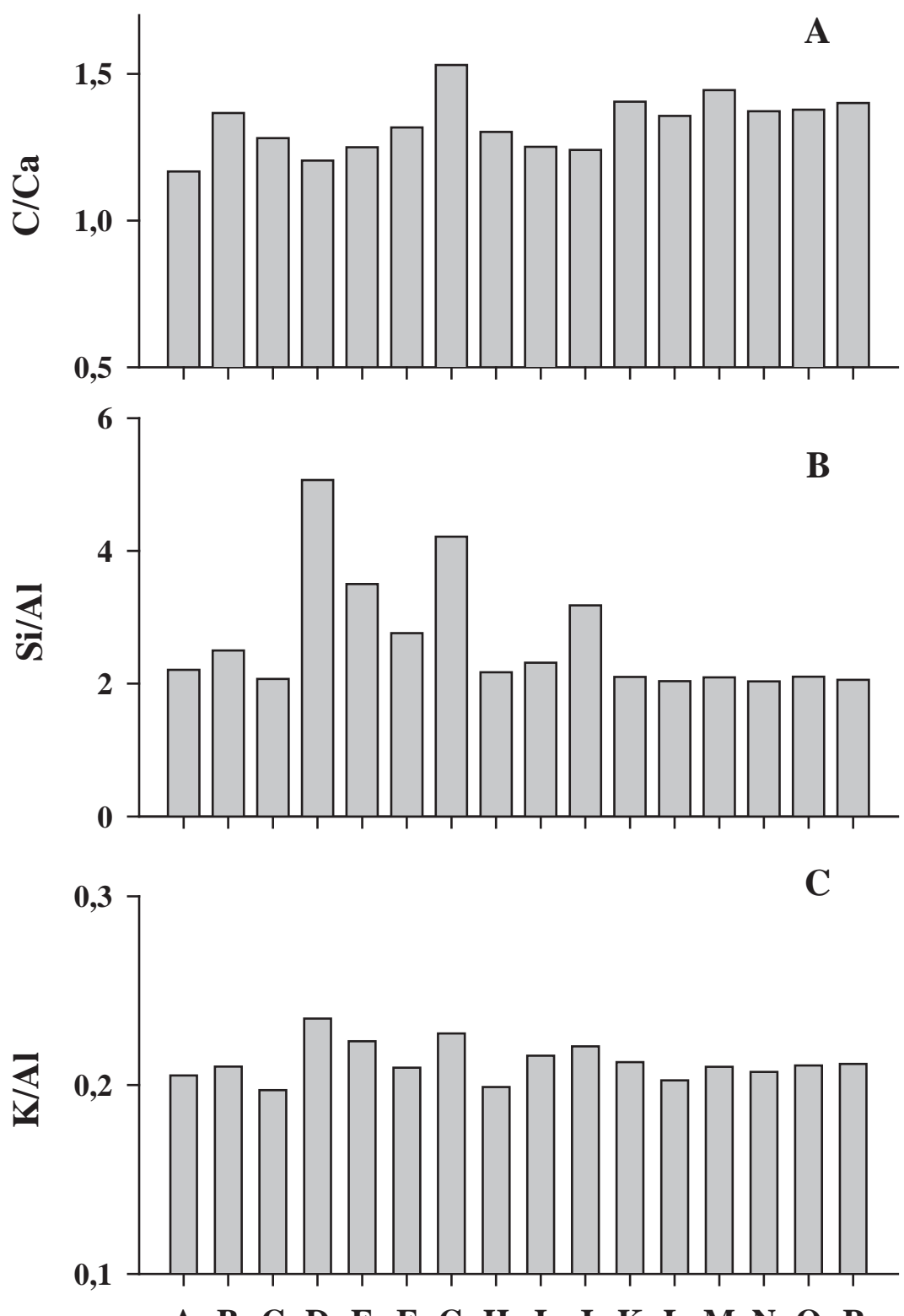

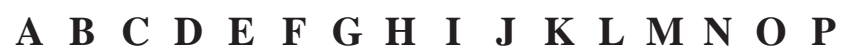

Figure 4. Spatial variation along the reservoir of the elemental quotiens $\mathrm{C} / \mathrm{Ca}(\mathrm{A}), \mathrm{Si} / \mathrm{Al}(\mathrm{B})$ and $\mathrm{K} / \mathrm{Al}(\mathrm{C})$ in the superficial sediment along the reservoir. Ratios expressed in atoms. Variación espacial a lo largo del embalse de los coeficientes elementales C/Ca (A), $\mathrm{Si} / \mathrm{Al}(\mathrm{B})$ y $\mathrm{K} / \mathrm{Al}(\mathrm{C})$. Cocientes expresados en átomos. 
$a l .$, 2006). The $\mathrm{Si} / \mathrm{Al}$ quotient is an indirect estimator of the proportion of quartz, associated with the sedimentation of thicker materials that require larger transport energy, and clays, associated with the sedimentation of finer materials that require little energy to be transported. The variability of the $\mathrm{Si} / \mathrm{Al}$ quotient along the reservoir (Fig. 4B), indicates that a greater proportion of quartz appears in the intermediate stations, especially in stations $\mathrm{G}, \mathrm{D}$ and $\mathrm{J}$; these zones are located where materials of greater size settle. This result is in agreement with the granulometric distribution discussed previously. The K/Al quotient is closely related to the nature and degree of weathering of the clays. In rocks, the average value of this quotient is approximately 0.24 , while in the highly weathered material usually transported by rivers, the value is relatively lower, as $\mathrm{K}$ is lost through mobilisation $(\mathrm{K} / \mathrm{Al}=0.15)$ (Viers et al., 2009). The sediment of Ribarroja presents an intermediate value, 0.21 , closer to that of rocks, indicating the presence of clays with an intermediate degree of weathering. The highest values for this quotient are measured in the stretch of river bends (stations D through K), where the least altered materials would be found, while in the final stretch and at the head of the reservoir lower quotients are measured, indicating the presence of more altered clays (Fig. 4C).

\section{Trace elements}

The mean concentrations of the trace elements analysed in the superficial sediment of Ribarroja are given in Table 4. Among the analysed elements, the ones most frequently associated with agricultural and/or industrial anthropogenic contamination are zinc $(\mathrm{Zn})$, copper $(\mathrm{Cu})$, nickel $(\mathrm{Ni})$, lead $(\mathrm{Pb})$, and chromium $(\mathrm{Cr})$. These elements can have adverse effects on the biota when their concentrations exceed certain limits. The observed concentrations for these elements are

Table 4. Mean concentration of trace elements in the superficial sediment of Ribarroja. $N=26$. Data in $\mu \mathrm{g} \cdot \mathrm{g}^{-1}$. As a comparison, the values of these metals in different types of materials are given: 2 Mean concentration in the sediment in suspension in rivers of the world (Viers et al., 2009); 3 Mean concentration in calcareous rocks (a: Guo et al., 1998; b: Potts et al., 1992). Concentración media de los elementos traza en los sedimentos superficiales de Ribarroja. $\mathrm{N}=26$. Datos en $\mu \mathrm{g} \cdot \mathrm{g}^{-1}$. Como comparación se dan valores de estos metales en diferentes tipos de materiales: 2 Concentración media en los sedimentos en suspensión en ríos del mundo (Viers et al., 2009): 3 Concentración media en rocas calcáreas (a: de Guo et al., 1998; b: de Potts et al., 1992).

\begin{tabular}{|c|c|c|c|c|}
\hline & Mean & 2 & 3 & \\
\hline $\mathrm{Zn}$ & 105.5 & 208.0 & 30.0 & $\mathrm{~b}$ \\
\hline $\mathrm{Cu}$ & 30.2 & 75.9 & 4.0 & b \\
\hline $\mathrm{Ni}$ & 30.9 & 74.5 & 5.0 & $\mathrm{~b}$ \\
\hline $\mathrm{Pb}$ & 24.0 & 61.1 & 13.0 & $\mathrm{~b}$ \\
\hline $\mathrm{Cr}$ & 56.8 & 130.0 & 10.0 & $\mathrm{~b}$ \\
\hline Mo & 2.2 & 3.0 & 0.5 & $\mathrm{a}$ \\
\hline $\mathrm{Nb}$ & 13.0 & 13.5 & 4.1 & $\mathrm{a}$ \\
\hline $\mathrm{Zr}$ & 97.5 & 160.0 & 29.0 & $\mathrm{a}$ \\
\hline $\mathrm{Y}$ & 17.3 & 21.9 & 3.9 & $\mathrm{a}$ \\
\hline $\mathrm{Sr}$ & 457.8 & 187.0 & 218.0 & $\mathrm{a}$ \\
\hline $\mathrm{Rb}$ & 114.4 & 78.5 & 21.0 & $\mathrm{a}$ \\
\hline $\mathrm{Th}$ & 11.9 & 12.1 & 1.6 & $\mathrm{a}$ \\
\hline $\mathrm{Ga}$ & 14.9 & 18.1 & 2.8 & $\mathrm{a}$ \\
\hline W & 3.7 & 2.0 & 0.3 & $\mathrm{a}$ \\
\hline $\mathrm{V}$ & 97.6 & 129.0 & 14.0 & $\mathrm{a}$ \\
\hline $\mathrm{Ce}$ & 40.1 & 73.6 & - & \\
\hline Co & 14.8 & 22.5 & 2.1 & $\mathrm{a}$ \\
\hline $\mathrm{Ba}$ & 318.6 & 522.0 & 374.0 & $\mathrm{a}$ \\
\hline
\end{tabular}


lower than those described for the material transported by the rivers, while the enrichment factor with respect to limestone (the ratio between concentrations in the sediment and in the rock) is higher for $\mathrm{Cu}, \mathrm{Ni}$, and $\mathrm{Cr}(7.5,6$ and 5.8, respectively) than for $\mathrm{Zn}$ and $\mathrm{Pb}$ (3.5 and 1.8, respectively). When comparing the results with the critical values of toxicity threshold (TEL) and probable level of toxicity (PEL) employed by other authors (Evans and Gottgens, 2007), it is important to note that $\mathrm{Zn}$ and $\mathrm{Pb}$ are always found at lower concentrations than the levels considered as the toxicity thresholds $\left(123 \mathrm{mg} \cdot \mathrm{g}^{-1}\right.$ and $35 \mathrm{mg} \cdot \mathrm{g}^{-1}$, respectively). The levels of $\mathrm{Cu}$ are close to the toxicity threshold $\left(35.7 \mathrm{mg} \cdot \mathrm{g}^{-1}\right)$ at stations L and M (entrance to the Matarraña and the station immediately upstream) and are lower across the rest of the reservoir, while the concentrations of $\mathrm{Cr}$ and $\mathrm{Ni}$ are above the toxicity threshold $\left(37 \mathrm{mg} \cdot \mathrm{g}^{-1}\right.$ and $18 \mathrm{mg} \cdot \mathrm{g}^{-1}$, respectively) throughout the reservoir, although at no point is the level of probable toxicity reached (90 $\mathrm{mg} \cdot \mathrm{g}^{-1}$ and $36 \mathrm{mg} \cdot \mathrm{g}^{-1}$, respectively).
To integrate all the available information on the concentration of trace elements in the sediment of Ribarroja, an analysis of principal components (PCA) was conducted, with the intention of reducing the high number of variables to a few combined variables. These variables were meant to integrate the previously unmanageable number of variables and associate them with the main processes that determine the chemical composition of the sediment. Following Kumke et al. (2005), the PCA was conducted on the normalised concentrations with respect to aluminium.

The analysis has allowed the extraction of four principal components that explain $84 \%$ of the variance. The first component explains $40 \%$ of the variance and is mainly determined by the concentrations of niobium $(\mathrm{Nb})$, zirconium $(\mathrm{Zr})$, yttrium $(\mathrm{Y})$, lead $(\mathrm{Pb})$, and zinc $(\mathrm{Zn})$, which present load factors higher than 0.85 , and to a lesser degree by vanadium (V) and cobalt (Co) (load factor $>0.75$ ) (Table 5). This component is also found to be narrowly correlated with the $\mathrm{Si} / \mathrm{Al}$ elemental quotient $\left(r^{2}=0.870, p<0.005\right)$.

Table 5. Percentage of variance explained by the four principal components and loads for the variables introduced in the PCA analysis. Only values higher than 0.500 are given. Porcentaje de la varianza explicada por las cuatro primeras componentes $y$ factores de carga de las variables usadas en el análisis de componentes principales. Solamente se muestran los valores superiores a 0.500

\begin{tabular}{lcccc}
\hline Component & 1 & 2 & 3 & 4 \\
\hline \% Variance explained & 40.1 & 67.9 & 76.3 & \\
$\mathrm{Mo}$ & & 0.787 & \\
$\mathrm{Nb}$ & 0.941 & & \\
$\mathrm{Zr}$ & 0.897 & & -0.530 \\
$\mathrm{Y}$ & 0.871 & & & \\
$\mathrm{Sr}$ & 0.710 & 0.823 & & \\
$\mathrm{Rb}$ & & & \\
$\mathrm{Th}$ & & 0.913 & \\
$\mathrm{Ga}$ & & & -0.541 \\
$\mathrm{Zn}$ & 0.877 & & \\
$\mathrm{~W}$ & & 0.741 & \\
$\mathrm{Cu}$ & & 0.955 & \\
$\mathrm{Ni}$ & & & \\
$\mathrm{V}$ & 0.785 & & \\
$\mathrm{Ce}$ & & & \\
$\mathrm{Co}$ & 0.761 & 0.534 & \\
$\mathrm{~Pb}$ & 0.920 & -0.611 & \\
$\mathrm{Ba}$ & 0.588 & & \\
$\mathrm{Cr}$ & 0.663 & & \\
\hline
\end{tabular}




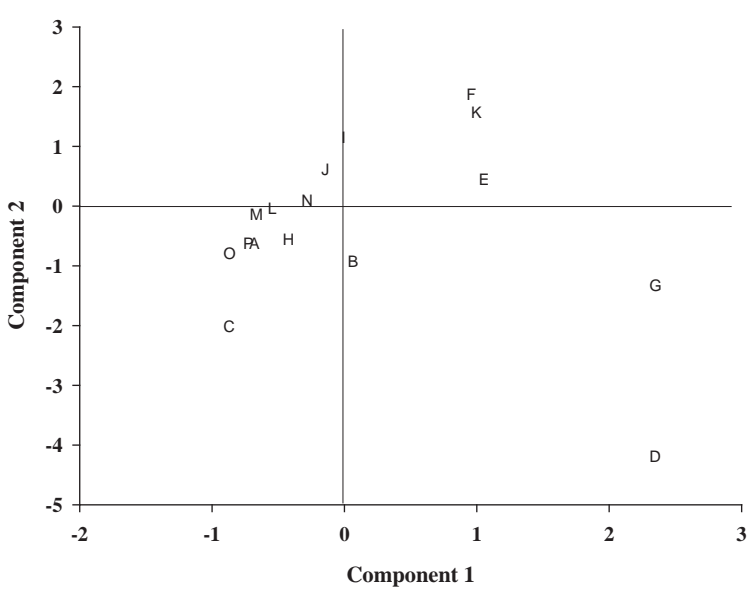

Figure 5. Values of the two first principal components in the superficial sediment of the different sampled stations along the reservoir. Valores de los dos componentes principales en los sedimentos superficiales de las diferentes estaciones muestreadas a lo largo del embalse.

All the elements associated with component 1 are characterised by the presence of elevated aluminium concentrations in dolomitic lime and in the earth crust, while the clays originating in the watershed are relatively poor in these elements. The impoverishment of $\mathrm{Pb}, \mathrm{Zn}, \mathrm{V}, \mathrm{Co}$, and $\mathrm{Cr}$ in the clays is due to its moderately high mobility. The impoverishment of zirconium, however, is due to the fact that this element is only lost in rock from physical but not from chemical weathering (Riebe et al., 2003). From these considerations, and in accordance with the observed correlations with the most common elements in the Ribarroja sediment, we can interpret component 1 as an estimate of the degree of chemical alteration of the sedimented materials. The highest values of this component correspond to the stations that present higher percentages of relatively unaltered materials, those with a significant amount of quartz and lime and a lower proportion of clays. The spatial variability of the component for the superficial sediment agrees with this interpretation, as higher values are found in the river bend zone (D, G, E, F, K) than on the dam and on the tail of the reservoir (A, C, P, M) (Fig. 5).

The $2^{\text {nd }}$ component, which explains $27.8 \%$ of the variance, is determined by the concentration of nickel (Ni), molybdenum (Mo), gallium (Ga), rubidium $(\mathrm{Rb})$, and copper $(\mathrm{Cu})$, and it is negatively correlated to the concentration of chromium (Table 5). Furthermore, it presents a significant correlation with the $\mathrm{N}$ concentration $\left(r^{2}=0.26, p<0.05\right)$. In the Ribarroja sediment, $\mathrm{Ni}$ and $\mathrm{Cu}$ present a relatively high enrichment coefficient (Table 4), and the association of these elements to the concentration of $\mathrm{N}$ suggests that the $2^{\text {nd }}$ component is related to a process of organic contamination. The transition metals, which include $\mathrm{Ni}$ and $\mathrm{Cu}$, can form colloids and aggregates with clay and organic material, which would explain the observed relationship. Molybdenum is a scarce element that frequently appears in association with nickel, which is why its association with component 2 is not unusual. The interpretation of the results as they pertain to gallium and rubidium is less evident. The concentration of gallium in the Ribarroja sediment is on the same order as the concentration observed in the earth crust or in clays originating in the watershed (Table 4), while the concentration of $\mathrm{Rb}$ is higher in these sources than it is in lime and earthly sediment. Although rubidium is a mobile element, it may be relatively enriched due to its higher adsorption affinity to clays, where it displaces lower atomic mass elements such as potassium (Kerr et al., 2008). In light of this information, the 2nd component may describe the process of formation of clay-organic matter-metal complexes. It should be noted that the negative correlation between this component and chromium suggests that, in the Ribarroja Reservoir, this element is linked to inorganic complexes. The spatial variability in the superficial sediment shows that the stations with higher values of this component are located in the central zone, especially stations F, K and I, while the lower values appear in those stations close to the tail (C and D).

Components 3 and 4, which explain $8.4 \%$ and $7.4 \%$ of the variance, respectively, are more difficult to interpret and seem to be related to the mineralogy of the basin. The elements that define both components, wolfram, thorium and cerium, are very minor and are found at very low levels in the Ribarroja sediment. The negative weight of the concentration of strontium with component 3 
suggests that it is related to presence of carbonates, (which contain low concentrations of thorium).

\section{Spatial heterogeneity}

In general terms, the sediment of Ribarroja is relatively homogeneous. Although important differences exist regarding the amount of sediment accumulation in different areas of the reservoir, there are no great differences in either the chemical or physical characteristics of the superficial sediment, reflecting a similar source of matter across the reservoir. The detailed analysis of the most and least abundant elements in the sediment, combined with the detailed study of the physical structure, allows for the distinction of different sedimentary areas, which reflect a process of selective sedimentation along the reservoir and cause a certain spatial heterogeneity of the sediment. These areas are described below, with emphasis on their most relevant characteristics.

\section{Upper stretch}

A great accumulation of sediment proceeding mostly from the Segre River is located in the upper stretch. From a qualitative point of view, two clearly differentiated areas can be distinguished. The first corresponds to the area before the entrance of the Segre River, next to the Mequinenza dam. In this area, the sediment is characterised by a mix of very fine materials, with an abundant contribution of highly altered materials and a scarcity of organic material and associated metals. However, because the finer fraction is not "diluted" by the presence of larger materials, the concentration per unit of dry weight of some metals, such as nickel, is relatively high.

The second area corresponds to the zone where the contributions from the Segre River have the most influence. This sediment is distinguished by its mixture of lime, highly weathered clay and barely altered sands. In addition, part of the lime corresponds to organic matter, which is found in moderate quantities. Along with the presence of this type of organic matter, the sediment presents moderate concentrations of copper, nickel, and zinc. In the reservoir zone between the entrance of the Segre River and the front of the sediment tongue (station $G$ ), the sediment presents characteristics that are compatible with the differential sedimentation of materials such as those found on the Segre River. The zone closest to the entrance to the river (station $\mathrm{B}$ ) is characterised by the predominance of more weathered materials; as the sediment front advances, less altered materials become more abundant. Less coherent materials, such as sands and very fine particles, are transported more easily, and these materials appear in larger proportions in the frontal zone of the sediment tongue (station $\mathrm{G}$ ) and in the littoral zone (station D). In these zones, the sediment appears to be formed by a heterogeneous mix of materials, with a low proportion of lime and a variable proportion of organic matter, which is greatest at the most advanced station $(G)$.

\section{Intermediate stretch}

This stretch, which includes the river meandering zone of the Ebro River, presents quite homogeneous characteristics. The sediments are of a lime-clay texture in which the dominant materials are those of lesser size. The organic matter of this section is associated with the lime portion, and its concentration increases downstream, with the highest concentrations of nutrients found at station $\mathrm{K}$. The levels of metal concentration are moderate-low, with intermediate values between those observed in the Segre River and in the advancing front (station $\mathrm{G}$ ). However, station $\mathrm{J}$ shows very different characteristics from the others in the stretch and is more similar to littoral station D. Just as at that location, the sediment is characterised by a heterogeneous mixture of clay, sands and a low percentage of lime. The organic matter is not associated to lime here, but the concentrations of $\mathrm{C}, \mathrm{N}$ and $\mathrm{P}$ are much greater than those observed in the littoral station of the upper stretch. Similarly, although the concentrations of metals in this station are inferior to the rest of the middle stretch (as expected from the lesser proportion of lime), they are clearly superior to those of station D. 


\section{Lower stretch}

The lower stretch of the reservoir, from slightly before the entrance to the Matarraña River to the Ribarroja Reservoir, presents some exceedingly homogeneous characteristics. As in the intermediate stretch, the sediment is characterised by a lime-clay texture, but although the proportion of lime is similar to that of the aforementioned stretch, the proportion of very fine materials increases slightly. The most abundant elements are those expected from highly weathered materials. The entrance of the Matarraña River has little effect on the composition of the sediment located downstream and is only notable due to a slight increase in the asymmetry of the distribution of the particle sizes behind the river entrance. Just as in the intermediate stretch, a portion of the organic matter is found in the lime fraction. A gradual increase in the concentration of nutrients, $\mathrm{N}$, and $\mathrm{P}$ in the sediment in the direction of water flow is detectable, with the highest concentrations being reached just before the Ribarroja dam (stations $\mathrm{O}$ and $\mathrm{P})$. The elevated proportions of lime and organic matter are in agreement with the larger concentrations of metals such as nickel, copper, and zinc, which are present in concentrations per unit of dry weight that are either similar to or higher than those observed in the Segre River. Nevertheless, if the lower presence of thick material in the final stretch of the reservoir relative to the Segre River is considered, the concentration of metals in the sediment of the final stretch is slightly lower than that detected in the river.

\section{ACKNOWLEDGEMENTS}

In this paper, the authors want to acknowledge the professors J. G. Tundisi and T. Matsumura Tundisi for their contributions to the knowledge of the ecology of the Brazilian continental waters. The studies of the limnology of reservoirs conducted by these scientists have been especially important to the development of a methodology to manage reservoirs and to minimise their impact. The Spanish Government (projects CGL2004-05503-C02-01 and 02, and
CGL2008-06377-C02-01 and 02) provided financial support for this study.

\section{REFERENCES}

ABRAMS, M. M. \& W. M. JARRELL. 1995. SoilPhosphorus as a Potential Nonpoint-Source for Elevated Stream Phosphorus Levels. J. Environ. Qual., 24(1): 132-138.

ANSELMETTI, F. S., R. BUHLER, D. FINGER, S. GIRARDCLOS, A. LANCINI, C. RELLSTAB \& M. STURM. 2007. Effects of Alpine hydropower dams on particle transport and lacustrine sedimentation. Aquat. Sci., 69(2): 179-198.

ARMENGOL, J., M. CRESPO, J. A. MORGUí \& A. VIDAL. 1986. Phosphorus budgets and forms of phosphorus in the Sau reservoir sediment: An interpretation of the limnological record. Hydrobiologia, 143: 331-336.

EVANS, J. E. \& J. F. GOTTGENS. 2007. Contaminant stratigraphy of the Ballville Reservoir, Sandusky River, NW Ohio: implications for dam removal. J.Great Lakes Res. 33: 182-193.

GARCIA, T., A. VELO, S. FERNANDEZ-BASTERO, L. GAGO-DUPORT, A. SANTOS, I. ALEJO \& F. VILAS. 2005. Coupled transport-reaction pathways and distribution patterns between siliciclastic-carbonate sediments at the Ria de Vigo. J. Mar. Syst., 54: 227-244.

GUO, S., T. C. LUO, B. R. ZHANG, H. F. ZHANG, Y. W. Z. HAN, D. ZHAO, \& Y. K. HU 1998. Chemical composition of the continental crust as revealed by studies in East China. Geochim.Cosmochim. Acta 62: 1959-1975

JENSEN, H. S., P. KRISTENSEN, E. JEPPESEN \& A. SKYTTHE. 1992. Iron-Phosphorus Ratio in Surface Sediment as an Indicator of Phosphate Release from Aerobic Sediments in Shallow Lakes. Hydrobiologia, 235: 731-743.

KERR, S. C., M. M. SHAFER, J. OVERDIER. \& D. E. ARMSTRONG. 2008. Hydrologic and biogeochemical controls on trace element export from northern Wisconsin wetlands. Biogeochemistry, 89: 273-294.

KIENEL, U. \& T. KUMKE. 2002. Combining ordination techniques and geostatistics to determine the patterns of diatom distribution at Lake Lama, Central Siberia. J. Paelolim., 28: 181-194. 
KUMKE, T., A. SCHOONDERWALDT \& U. KIENEL. 2005. Spatial variability of sedimentological properties in a large Siberian lake. Aquat. Sci., 67: 86-96.

LOIZEAU, J. L., J. DOMINIK, T. LUZZI \& J. P. VERNET. 1997. Sediment core correlation and mapping of sediment accumulation rates in Lake Geneva (Switzerland, France) using Volume Magnetic Susceptibility. J. Great Lakes Res., 23: 391402.

LOPEZ, P. 2009. Los sedimentos y su incidencia en la eutrofización de los embalses. Caso del río Lozoya. Ingeniería del Agua, 16: 273-283.

LOPEZ, P. \& J. A. MORGUI. 1993. Factors Influencing Fractional Phosphorus Composition in Sediments of Spanish Reservoirs. Hydrobiologia, 253: 73-82.

LOPEZ, P., R. MARCE, J. ORDONEZ, I. URRUTIA \& J. ARMENGOL. 2009. Sedimentary phosphorus in a cascade of five reservoirs (Lozoya River, Central Spain). Lake Reserv. Manage., 25: 39-48.

LOPEZ, P., E. NAVARRO, R. MARCE, J. ORDONEZ, L. CAPUTO \& J. ARMENGOL. 2006. Elemental ratios in sediments as indicators of ecological processes in Spanish reservoirs. Limnetica, 21: 499-512.

NURNBERG, G. K. 1999. Determining trophic state in experimental lakes. Limnol.Oceanogr., 44: 1176-1179.

POTTS, P. J., A. G. TINDLE \& P. C. WEBB 1992. Geochemical reference material compositions: rocks, minerals, sediments, soils, carbonates. CRC. RIEBE, C. S., J. W. KIRCHNER \& R. C. FINKEL. 2003. Long-term rates of chemical weathering and physical erosion from cosmogenic nuclides and geochemical mass balance. Geochim. Cosmochim. Acta, 67(22): 4411-4427.

ROURA, M. 2004. Incidència de l'Embassament de Mequinensa en el transport de sòlids en suspensió i la qualitat de l'aigua del riu Ebre. Tesis Doctoral, Universidad de Barcelona. 236 pp.

STEVENS, R. L., H. BENGTSSON \& A. LEPLAND. 1996. Textural provinces and transport interpretations with fine-grained sediments in the Skagerrak. J. Sea Res., 35: 99-110.

SWARTZ, R. C., W. A. DEBEN, K. A. SERCU \& J. O. LAMBERSON. 1982. Sediment Toxicity and the Distribution of Amphipods in Commencement Bay, Washington, United-States. Mar. Pollut. Bull., 13: 359-364.

TUNDISI, J. G. \& T. MATSUMURA TUNDISI. 2008. Limnologia. Oficina de Textos, Sao Paulo, SP. Brasil. 631 pp.

VIERS, J., B. DUPRE \& J. GAILLARDET. 2009. Chemical composition of suspended sediments in World Rivers: New insights from a new database. Sci.Total Environ. 407(2): 853-868.

ZONTA, R., L. ZAGGIA \& E. ARGESE. 1994. Heavy-Metal and Grain-Size Distributions in Estuarine Shallow-Water Sediments of the Cona Marsh (Venice Lagoon, Italy). Sci. Total Environ. 151: 19-28. 